Article

\title{
Examining the Influence of Sludge from Municipal Wastewater Treatment Plants Processed by Euphore Installations on the Quantity and Quality of Rapeseed and Soybean Production
}

\author{
Esmeralda Chiorescu (D) and Feodor Filipov *
}

Citation: Chiorescu, E.; Filipov, F. Examining the Influence of Sludge from Municipal Wastewater Treatment Plants Processed by Euphore Installations on the Quantity and Quality of Rapeseed and Soybean Production. Agriculture 2021, 11, 278. https://doi.org/10.3390/ agriculture11040278

Academic Editors: Mohsin Tanveer, Mirza Hasanuzzaman and Ejaz Ahmad Khan

Received: 31 January 2021

Accepted: 22 March 2021

Published: 24 March 2021

Publisher's Note: MDPI stays neutra with regard to jurisdictional claims in published maps and institutional affiliations.

Copyright: (c) 2021 by the authors. Licensee MDPI, Basel, Switzerland. This article is an open access article distributed under the terms and conditions of the Creative Commons Attribution (CC BY) license (https:/ / creativecommons.org/licenses/by/ $4.0 /)$.
Faculty of Agriculture, University of Agricultural Sciences and Veterinary Medicine, 3 Mihail Sadoveanu Alley, 700490 Iasi, Romania; echiorescu@uaiasi.ro

* Correspondence: ffilipov@uaiasi.ro

\begin{abstract}
Sludge management is a complex issue due to the environmental standards. It is required that the wastewater treatment activity be in close connection with the controlled recovery and storage of sludge. Thus, by using sludge in agriculture, nutrients essential for plant development can be recycled and some soil properties can be improved. The purpose of this paper was to present some results on the influence of municipal sludge treated and processed in a Euphore plant on the quantity and quality of rapeseed and soybean production. This technology allows for the recovery of the constituents of phosphorus, nitrogen, potassium, sulfur, magnesium, calcium, manganese, zinc, and copper. Our experimental data revealed that the obtained yield of Pioneer PT225 rapeseed hybrid was $5200 \mathrm{~kg} / \mathrm{ha}$ in the variant treated with the Euphore process compared to that of the control variant at only $2356 \mathrm{~kg} / \mathrm{ha}$. For the Condor variety soybean crop, the highest average number of pods obtained per plant was 195.3 compared 88 pods per plant in the control variant. Thus, the sludge obtained from urban wastewater treatment plants processed using the Euphore method is a good source of macro and micronutrients in agriculture, without having a negative impact on the environment.
\end{abstract}

Keywords: sewage sludge; Euphore technology; rapeseed; soybean

\section{Introduction}

An important challenge in wastewater management is the use of sewage sludge, which can be an important source of nutrients for agriculture, being rich in $\mathrm{N}, \mathrm{P}, \mathrm{K}$, organic matter, and other elements that can stimulate plant development [1-3].

Thus, the use of sludge in agriculture has become an alternative for the use of waste for economic and practical reasons [4-6].

In the European Union, the ecological capitalization of sewage sludge has been at the center of attention of producers with the implementation of EEC (European Economic Community)-(Directive 91/271, on urban wastewater treatment [7,8]. Thus, at the level of European states, the amount of sludge used in agriculture has increased in the last 15 years from 3,000,000 tonnes dry substance/year to 6,100,000 tonnes dry substance/year in 2020 [9-11].

In Romania, the amount of sewage sludge has increased in the last eight years from about 80,000 tonnes dry substance/year to about 416,000 tonnes dry substance/year in 2020 [12].

Two areas of major importance are the method for treating the sludge in such a way as to comply with the European Union Directives and how to apply it as a fertilizer in order to obtain healthy crops, preserve the fertility of the soil, and ensure environmental protection $[13,14]$.

The progressive implementation of the Urban Wastewater Treatment Directive 91/271/EEC in all member states is increasing the quantities of sewage sludge requiring disposal. Sludge can 
be concentrated in heavy metals [15-21], poorly biodegradable trace organic compounds, and potentially pathogenic organisms (viruses, bacteria, etc.) that are present in wastewater [22-25], therefore, the capitalization of sludge must be in accordance with the Sewage Sludge Directive 86/278/EEC [26] that seeks to encourage the use of sewage sludge in agriculture and to regulate its use in such a way as to prevent harmful effects on soil, vegetation, animals, and man.

When applying the sludge, the climatic and soil conditions in the areas near their processing stations must also be taken into account [26-30].

Through research-development activity and the implementation of top technology regarding the renewable energy resources, in Germany, the capitalization of the sewage sludge experienced a considerable increase from $9 \%$ to $53.2 \%$ (an increase of $491 \%$ ), from the total sludge produced, with a humidity of $60 \%$ [31,32].

One of the most advanced German technologies for sludge treatment is the Euphore method, which aims in particular at reducing pollutants and recovering valuable components from sludge and reintroducing them into the economic cycle. It eliminates most of the technological disadvantages of the existing competing technologies, which are usually a combination of incineration and subsequent thermochemical treatment.

Due to the significant energy content of sludge, along with that of phosphorus in particular, thermo-chemical recovery processes now have much more efficient results than purely thermal or chemical processes and allow for an almost complete recycling of nutrients [33].

The Euphore-type sewage sludge treatment plant (Figure 1) together with its reactor (Figure 2) offers the possibility to use both natural gas and cogeneration or biogas waste gas.

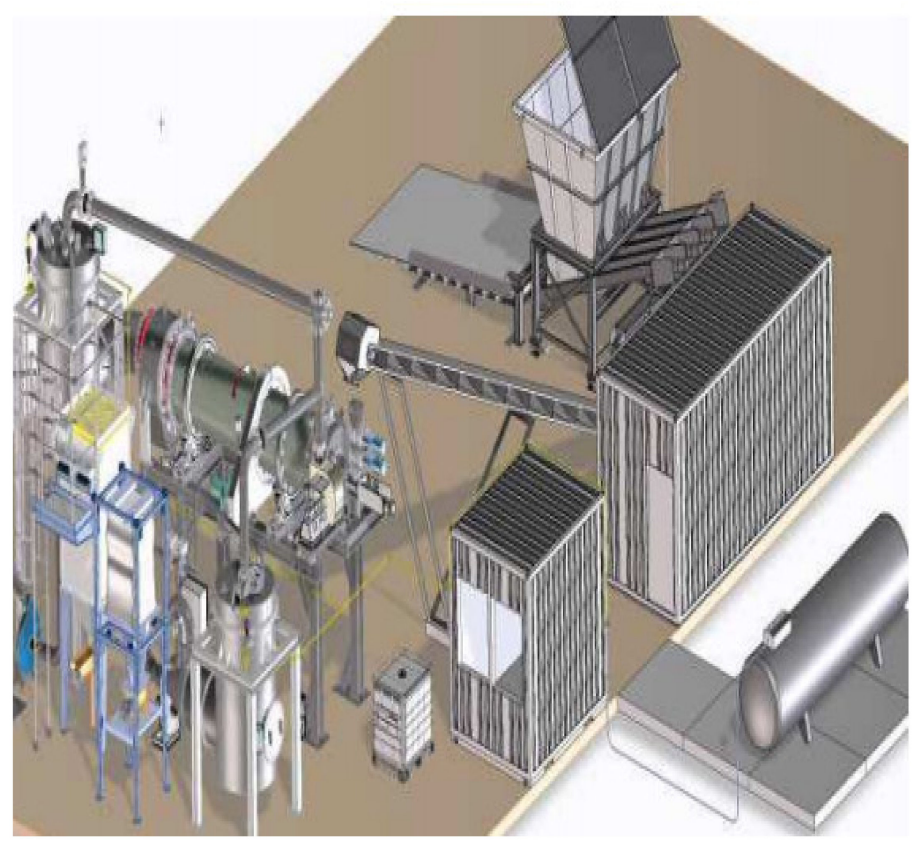

Figure 1. Euphore-type thermochemical treatment plant.

Drying uses the pure waste gas stream of a cogeneration plant and is therefore an energy source that would otherwise be lost to the atmosphere. A pure waste gas stream contains $50 \%$ of the thermal energy of a cogeneration plant. With the help of hot waste gases of $550-600{ }^{\circ} \mathrm{C}$, drying is achieved at an evaporation capacity of $600 \mathrm{~W}$ per liter of water, thus achieving an unprecedented efficiency. The sewage sludge is transported through a controlled and fully automated process through the drying chambers. Depending on the user, the degree of drying can be set and can vary between 80 and $95 \%$ dry substance. The entire exhaust air passes through an integrated fine filtration system, which almost completely retains dust, ash, and other solid components. To remove olfactory pollution (odors), the air is treated in a biofilter. The fine dust resulting from the filtration chamber 
falls into a screw conveyor and is transported to the discharge chamber, where it is mixed with the dried sludge and then hermetically transported in an intermediate container. By applying the hot gas, a complete sanitization of the sludge is carried out, destroying pathogens such as viruses, bacteria, endotoxins, fungi, protozoa, and worms, in addition to evaporating the water. By using waste gas, the sewage sludge can be treated and dried without emissions. The waste gas drying system transforms a tonne of wastewater full of noxious substances into $250 \mathrm{~kg}$ of sanitized biomass, from which nutrients can be recovered. The installation can also be provided with a pelletizer, specially designed so as not to emit dust and other emissions, which produces a dry and pelletized sludge, ideal for further recovery both as agricultural fertilizer and for gasification or combustion.

All processes are easy to view and monitor using Wireless ARC (Active Radio Control) technology.

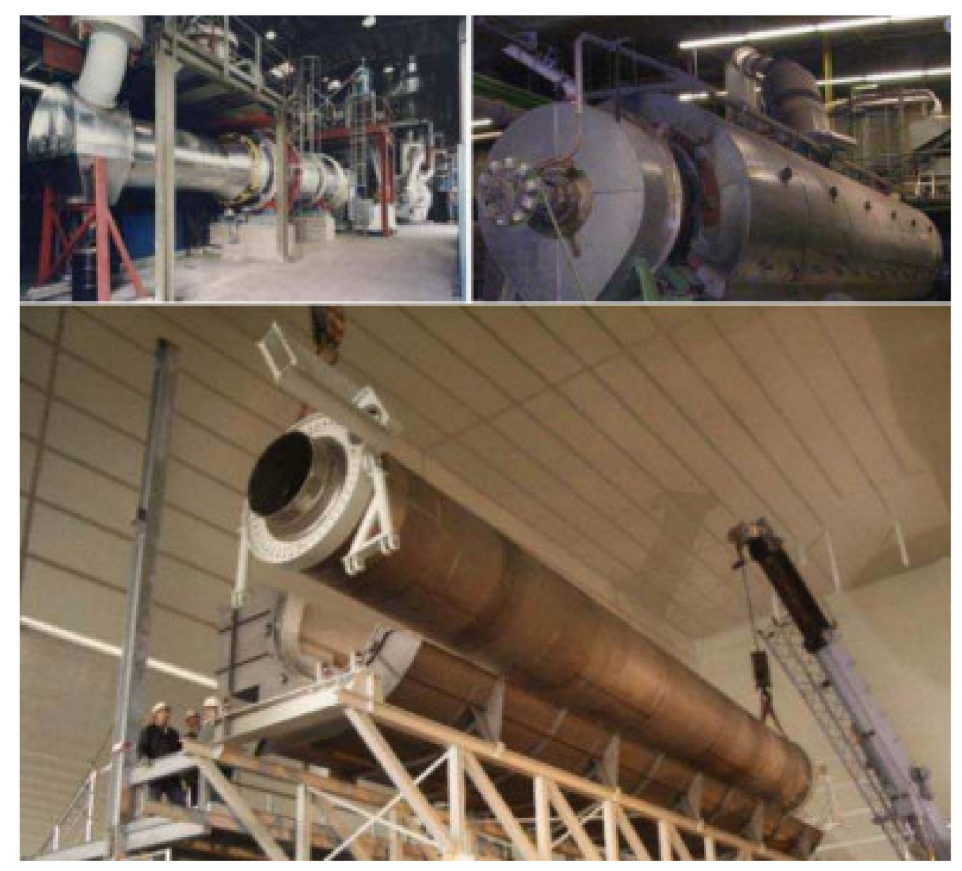

Figure 2. Reactor for Euphore-type treatment.

\section{Materials and Methods}

The main purpose of this paper was to present the influence of sludge from municipal treatment plants processed by Euphore-type installations on rapeseed and soybean crops, whilst respecting protection rules imposed by the EU and encouraging farmers to use products resulting from innovative sludge treatment techniques. Representative soil profiles were developed at the studied location.

The experimental field was located in Fălticeni on a Luvic stagnic Phaeozems or Faeoziom clinogleic soil type, as defined in the Romanian Soil Taxonomy System [34]. In the field, we collected soil samples to conduct laboratory analyses [35]. Where the samples were collected, images related to the aspect of the soil profile were taken with a digital camera.

Luvic stagnic Phaeozems (Figure 3) has a loamy-clay texture and medium-to-good fertility with a moderate humus content $(3.1 \%)$ and relatively high total nitrogen, and medium levels of mobile phosphorus and potassium. The soil is slightly acidic $(\mathrm{pH}=6.3)$.

Chemical and mineralogical characterizations of the sludge were performed in a laboratory based on SEM/EDX analysis. The chemical analysis of the sludge was based on the following methods: determination of the $\mathrm{pH}$ by the method SR EN 12176/2000, humidity U (\%)—SR EN 12880, total organic carbon—SR EN 12880, nitrogen—STAS 12200/85, phosphorus- 
STAS 12205/84, potassium-STAS 12678/88, cadmium STAS—128 76/90, chromium—STAS

13117/92, copper-SR 13179/93, Ni-STAS 13094/92, Pb-SR 13225/94, and Zinc-SR 13181/93.

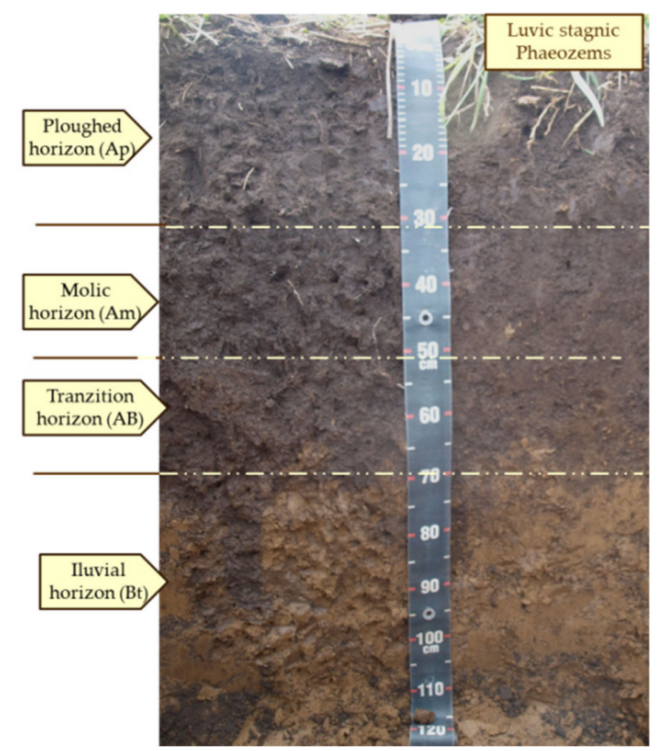

(a)

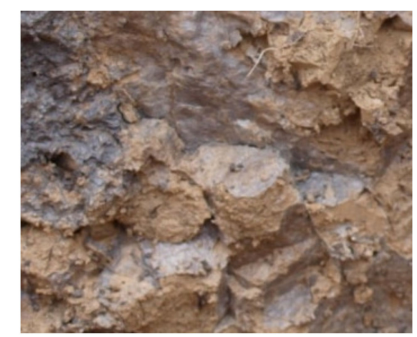

(b)

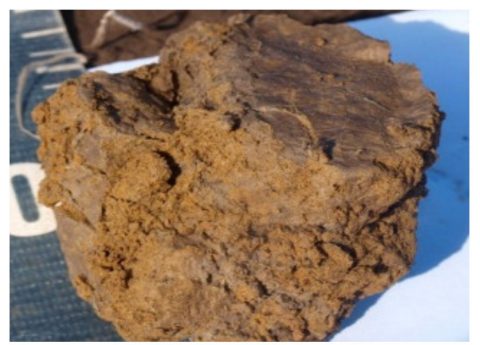

(c)

Figure 3. Profile of stagnic Phaeozems (a), complex clay-humic cutans on the faces of the structural aggregates (b), and fragment of prismatic aggregate with rediximorphic colors (c).

The types of sludge that were studied had the following characteristics: specific density, $\mathrm{rs}=1.65-1.85 \mathrm{~g} / \mathrm{cm}^{3}$; density, $\mathrm{r}=1.05-1.12 \mathrm{~g} / \mathrm{cm}^{3}$; upper limit of plasticity, $\mathrm{wL}=100-333 \%$; lower limit of plasticity, $\mathrm{wP}=42-218 \%$; linear contraction, $11 \%$, free swelling, $1.21-1.285 \%$; pore index, $\mathrm{e}=1.25-5.15$; compression index, $\mathrm{C} \mathrm{C}=0.38-1.68$; secondary consolidation coefficient, Cs $=0.04-0.25$; permeability coefficient, $\mathrm{k}=10^{-7}-10^{-11} \mathrm{~m} / \mathrm{s}$; volume compressibility coefficient, $\mathrm{mn}=2 \mathrm{~m}^{2} / \mathrm{MN}$; consolidation coefficient, $\mathrm{cn}=0.039-1.1 \mathrm{~m}^{2} /$ year; optimal Proctor compaction humidity, woc $=39-53 \%$; maximum dry weight, gdmax $=8.2 \mathrm{kN} / \mathrm{m}^{3}$; internal friction angle, $\mathrm{f}=37-45.5^{\circ}$; cohesion, $\mathrm{c}=14.25-46.35 \mathrm{kPa}$; and undrained shear strength, $\mathrm{su}$ (Vane test) $=138-155 \mathrm{kPa}$. All these characteristics contribute to the soil structure.

The treatment of soil samples that were collected for the tests was in accordance with the standard SR ISO 11464/1998: soil quality, samples pre-treatment for physical-chemical tests. Therefore, samples were dried in the stove and were hashed with an electric soil mill. The heavy metals used were $\mathrm{Cd}, \mathrm{Cu}, \mathrm{Zn}$, and $\mathrm{Pb}$. Heavy metals determination was made in accordance with the standard SR ISO11047/1999S: soil quality, through atomic absorption spectrometry.

Metals extraction was completed with concentrated sulphuric acid and oxygenate water 50\%, with a mineralisator type Digestal HACH (Standard SR ISO 11047/1999: Soil quality).

Table 1 shows the compositions of the main elements for naturally dried sludge compared to those of Euphore sludge. It can be seen that Euphore-type sludge, through its specific phosphorus recovery technology, contains about 2.55 times more phosphate, with $1.1 \%$ more $\mathrm{N}$, and $2.5 \%$ more $\mathrm{K}$ compared to that of naturally dried sludge. Phosphates are readily available to plants and can be combined with other fertilizing ingredients.

The experiments performed were multifactorial of the $\mathrm{A} \times \mathrm{B} \times \mathrm{C}$ type. The placement of the experiments was done according to the "subdivided plots method" in three repetitions. Experimental factors took into account soil fertilization with various application doses (between 5-35 t/ha): 1—unfertilized soil, i.e., control sample soil (V1); 2 -organic fertilization with urban sludge treated by innovative Euphore-type installations (V2); and 3-organic fertilization with dry urban sludge from the Fălticeni treatment 
plant (V3).The crops studied were autumn rapeseed and soybeans. The biological material consisted of plant samples (parts, organs, products) from these crops during their vegetation period.

Table 1. Sludge composition.

\begin{tabular}{cccc}
\hline & $\begin{array}{c}\text { Sludge Used in Agriculture } \\
\text { CMA, D. 86/278/EEC, } \\
\text { mg/kg Dry Substance } \\
\text { (CMA = Maximum } \\
\text { Allowable } \\
\text { Concentration) }\end{array}$ & $\begin{array}{c}\text { Naturally Dried Sludge/ } \\
\text { Value kg Dry Substance }\end{array}$ & $\begin{array}{c}\text { Dried Sludge } \\
\text { Euphore } \\
\text { Installation/Value kg Dry } \\
\text { Substance }\end{array}$ \\
\hline Humidity & - & & $6 \%$ \\
pH & - & $38 \%$ & 7.93 \\
Nitrogen & - & 6.92 & $3.5 \%$ \\
Phosphate & - & $2.4 \%$ & $24 \%$ \\
Potassium & - & $9.4 \%$ & $5.2 \%$ \\
Cadmium & $20-40 \mathrm{mg}$ & $2.5 \%$ & $3.6 \mathrm{ppm}$ \\
Copper & $1000-1750 \mathrm{mg}$ & $3.8 \mathrm{ppm}$ & $165.57 \mathrm{ppm}$ \\
Nickel & $300-400 \mathrm{mg}$ & $166.35 \mathrm{ppm}$ & $5.2 \mathrm{ppm}$ \\
Lead & $750-1200 \mathrm{mg}$ & $5.6 \mathrm{ppm}$ & $19.58 \mathrm{ppm}$ \\
Zinc & $2500-4000 \mathrm{mg}$ & $20.15 \mathrm{ppm}$ & $1355 \mathrm{ppm}$ \\
Chromium & $500 \mathrm{mg}$ & $1362 \mathrm{ppm}$ & $91.75 \mathrm{ppm}$ \\
\hline
\end{tabular}

The experimental area was divided into rectangular plots with areas of 10 square meters. In the research performed, soybean/rapeseed were selected for each variant, $N_{p}=28$ plots were allocated, and for the average crop productions and rapeseed oil content $\mathrm{N}_{\mathrm{obs}}=1$ observations were made. The means of the differences between the analyzed and control variants (mean of experience) were determined and interpreted using the Duncan's new multiple range test (MRT) and the limit difference test (DL) [36].

ISO 659:2009 specifies a reference method for the determination of the hexane extract (or light petroleum extract), called the "oil content", of oilseeds used as industrial raw materials [37].The oil content of rapeseed, according to ISO 659:2009, was measured directly by grinding the seed and extracting the oil using a 2055 Soxtec Manual Extraction Unit (Soxtec Avanti, Foss).This method is the reference method for oil content and is recommended by the Federation of Oils, Seeds and Fats Associations Ltd. (FOSFA) International in its list of official methods of analysis [38].

\section{Results and Discussion}

For the soybean crops, the Condor variety was chosen. Soybeans were sown with about 50-55 seeds per square meter on 1 April 2020, at a depth of about $3 \mathrm{~cm}$. The sowing was done in strips of three rows with a distance of $45 \mathrm{~cm}$ between them. The distance between the strips was $60 \mathrm{~cm}$. Irrigation was completed by sprinkling, with a watering rate of about $750 \mathrm{~m}^{3} /$ ha.

In Table 2 we can observe the soybean crop production in the nine experimental variants. On average, production obtained for the soil treated with Euphore-type sludge was about $30.6 \%$ higher than that of the control soil and about $12 \%$ compared to that of the soil treated with dry raw sludge.

To determine which of the nine variants, $\mathrm{T} 1, \mathrm{~T} 2, \ldots, \mathrm{T} 9$, were significant and which were insignificant, the algorithm related to Duncan's new multiple range test (MRT) was applied. Then, applying the test based on the limit difference, DL, a classification of the variants was made from the point of view of their representativeness. The Table 3 shows the values for the average soybean crop production, in descending order. 
Table 2. Soybean average crop production in the nine experimental variants.

\begin{tabular}{cccc}
\hline $\begin{array}{c}\text { Dosage of } \\
\text { Applied Sludge (t/ha) }\end{array}$ & $\begin{array}{c}\text { Control Soil Untreated with } \\
\text { Sludge } \\
\text { Production kg/ha }\end{array}$ & $\begin{array}{c}\text { Soil Treated with Euphore } \\
\text { Type Sludge } \\
\text { Production kg/ha }\end{array}$ & $\begin{array}{c}\text { Soil Treated with Dry Raw Sludge } \\
\text { on Treatment Plant Platform } \\
\text { Production kg/ha }\end{array}$ \\
\hline 15 & & $\mathrm{~T} 2=3265$ & $\mathrm{~T} 6=2994$ \\
25 & $\mathrm{~T} 1=2880$ & $\mathrm{~T} 3=3443$ & $\mathrm{~T} 7=3072$ \\
35 & & $\mathrm{~T} 4=3555$ & $\mathrm{~T} 8=3146$ \\
$\mathrm{~T} 5=3761$ & 3226 \\
\hline
\end{tabular}

Table 3. Values for the average soybean crop production, in descending order.

\begin{tabular}{ccccccccccc}
\hline Rank, $\boldsymbol{r}$ & $\mathbf{1}$ & $\mathbf{2}$ & $\mathbf{3}$ & $\mathbf{4}$ & $\mathbf{5}$ & $\mathbf{6}$ & $\mathbf{7}$ & $\mathbf{8}$ & $\mathbf{9}$ & Mean \\
\hline Variant & $\mathrm{T} 5$ & $\mathrm{~T} 4$ & $\mathrm{~T} 3$ & $\mathrm{~T} 2$ & $\mathrm{~T} 9$ & $\mathrm{~T} 8$ & $\mathrm{~T} 7$ & $\mathrm{~T} 6$ & $\mathrm{~T} 1$ & - \\
Average soybean production, $S_{r},(\mathrm{~kg} / \mathrm{ha})$ & 3761 & 3555 & 3443 & 3265 & 3226 & 3146 & 3072 & 2994 & 2880 & $\bar{S}=3260$ \\
Standard error, $\sigma_{r},(\mathrm{~cm})$ & 23.84 & 27.03 & 28.51 & 29.43 & 31.14 & 24.79 & 25.44 & 26.05 & 26.71 & $\bar{\sigma}=26.9946$ \\
\hline
\end{tabular}

On the last line of Table 3, the values for standard error, $\sigma_{r}$, related to the determination of the values for average soybean crop production, were also centralized. In the following, the multiple range test (MRT) uses only the average value $\bar{\sigma}=0.464$. In the statistical analysis related to the MRT, the following quantities are used as basic data:

- $\quad$ probability of transgression, $\alpha$;

- $\quad$ degrees of freedom for the observations, $p$;

- $\quad$ degrees of freedom, $\gamma$ for estimating the standard error.

At the same time the MRT also uses the following statistical functions:

- $\gamma(p, v, \alpha)=$ the quantile of the studentized range distribution;

- $\quad R(p, v, \alpha)=$ the shortest significant range (the actual critical value of the test).

For the probability of transgression, $\alpha=5 \%=0.05$ was considered.

The degrees of freedom, $p$, takes all the values from the set $\{2,3, \ldots, N V\}$, where $N V$ represents the number of variants; in the present paper $N V=9$.

The degrees of freedom, $v$ were determined with the following equation:

$$
v=N_{p} \cdot N_{o b s}-1
$$

where: $N_{p}$ is the number of plots assigned to a variant, and $N_{o b s}$ is the number of observations made on each plot.

In the research performed, for each variant, $N_{p}=28$ plots were allocated (with an area of $10 \mathrm{~m}^{2}$ ) and $N_{o b s}=1$ observations were made; thus, for each variant, the degrees of freedom presents the value:

$$
v=28 \cdot 1-1=27
$$

The standardized critical values for $\gamma(p, v, \alpha)$ were obtain from the table corresponding to the value, $\alpha=0.05$ [39].

The values thus determined are summarized in Table 4 , second row, where, because $v=27=$ const. and $\alpha=0.05=$ const., the notation was used: $\gamma_{p}=\gamma(p)$.

Table 4. Standardized critical values for functions $\gamma_{p}=\gamma(p)$ and $R_{p}=R_{(p)}$.

\begin{tabular}{ccccccccc}
\hline Degrees of Freedom for Observations, $\boldsymbol{p}$ & $\mathbf{2}$ & $\mathbf{3}$ & $\mathbf{4}$ & $\mathbf{5}$ & $\mathbf{6}$ & $\mathbf{7}$ & $\mathbf{8}$ & $\mathbf{9}$ \\
\hline Standardized critical value, $\gamma_{p}$ & 2.9 & 3.05 & 3.15 & 3.21 & 3.26 & 3.3 & 3.33 & 3.36 \\
Shortest critical range, $R_{p}$ & 63.18 & 66.38 & 68.45 & 69.91 & 71.01 & 71.87 & 72.54 & 73.1 \\
\hline
\end{tabular}


The shortest critical range is computed as:

$$
R(p, v, \alpha)=\bar{\sigma} \cdot \gamma(p, v, \alpha)
$$

The values for the shortest critical range are summarized in Table 4, third row, where the notation $R_{p}=R(p)$ was used.

An algorithm for performing the MRT test is as follows:

1. For each $\mathrm{m}_{\mathrm{i}}$ sample mean $\left(\mathrm{H}_{\mathrm{i}}\right)$, from largest to smallest, the differences are calculated:

$$
\left(\Delta_{i, j}\right)_{k}=\left(m_{i}-m_{j}\right)_{k}=\left(S_{i}-S_{j}\right)_{k}
$$

with:

$$
k=1,2, \ldots N_{\Delta}
$$

where:

$i,\left(i=1,2, \ldots, N_{V}\right)$ is designated as the Superior Rank of variants, and

$j,\left(j=N_{V}, N_{V-1}, \ldots, 2\right)$ is designated as the Inferior Rank of variants.

2. The values for shortest significant range, $\left(R_{p}\right)_{k}$ were taken from Table 4 , where $p=j-\mu$, with $\mu=0,1, \ldots \ldots, N_{v}-2, p \geq 2$.

3. The values for the Ranks of variants, $i$ and $j$, as well as for the difference $\left(\Delta_{i, j}\right)_{k}$ with the values $\left(R_{p}\right)_{k}$ are compared: $\left(\Delta_{i, j}\right)_{k}<\left(R_{p}\right)_{k}$ or $\left(\Delta_{i, j}\right)_{k}-\left(R_{p}\right)_{k} \leq 0$.

- 3.1. If $\left(\Delta_{i, j}\right)_{k}>\left(R_{p}\right)_{k}$ or $\left(\Delta_{i, j}\right)_{k}-\left(R_{p}\right)_{k}>0$ the variants used in the difference $\left(\Delta_{i, j}\right)_{k}$ are significant.

- 3.2. If $\left(\Delta_{i, j}\right)_{k}<\left(R_{p}\right)_{k}$ or $\left(\Delta_{i, j}\right)_{k}-\left(R_{p}\right)_{k} \leq 0$ the variants used in the difference $\left(\Delta_{i, j}\right)_{k}$ are insignificant.

The values for the ranks of variants, $i$ and $j$, as well as for the index $p$ are shown

\begin{tabular}{|c|c|c|c|c|c|c|c|c|c|}
\hline Difference between Pairs of Variants, $k$ & 1 & 2 & 3 & 4 & 5 & 6 & 7 & 8 & 9 \\
\hline Superior Rank of variants, $i$ & 1 & 1 & 1 & 1 & 1 & 1 & 1 & 1 & 2 \\
\hline Inferior Rank of variants, $j$ & 9 & 8 & 7 & 6 & 5 & 4 & 3 & 2 & 9 \\
\hline Index $p$ for shortest significant range, $R_{p}$ & 9 & 8 & 7 & 6 & 5 & 4 & 3 & 2 & 8 \\
\hline Difference between pairs of variants, $k$ & 10 & 11 & 12 & 13 & 14 & 15 & 16 & 17 & 18 \\
\hline Superior Rank of variants, $i$ & 2 & 2 & 2 & 2 & 2 & 2 & 3 & 3 & 3 \\
\hline Inferior Rank of variants, $j$ & 8 & 7 & 6 & 5 & 4 & 3 & 9 & 8 & 7 \\
\hline Index $p$ for shortest significant range, $R_{p}$ & 7 & 6 & 5 & 4 & 3 & 2 & 7 & 6 & 5 \\
\hline Difference between pairs of variants, $k$ & 19 & 20 & 21 & 22 & 23 & 24 & 25 & 26 & 27 \\
\hline Superior Rank of variants, $i$ & 3 & 3 & 3 & 4 & 4 & 4 & 4 & 4 & 5 \\
\hline Inferior Rank of variants, $j$ & 6 & 5 & 4 & 9 & 8 & 7 & 6 & 5 & 9 \\
\hline Index $p$ for shortest significant range, $R_{p}$ & 4 & 3 & 2 & 6 & 5 & 4 & 3 & 2 & 5 \\
\hline Difference between pairs of variants, $k$ & 28 & 29 & 30 & 31 & 32 & 33 & 34 & 35 & 36 \\
\hline Superior Rank of variants, $i$ & 5 & 5 & 5 & 6 & 6 & 6 & 7 & 7 & 8 \\
\hline Inferior Rank of variants, $j$ & 8 & 7 & 6 & 9 & 8 & 7 & 9 & 8 & 9 \\
\hline Index $p$ for shortest significant range, $R_{p}$ & 4 & 3 & 2 & 4 & 3 & 2 & 3 & 2 & 2 \\
\hline
\end{tabular}
in Table 5.

Table 5. The values for the ranks of variants, $i$ and $j$, as well as for the index $p$.

In Table 6, because the observed differences $\left(\Delta_{i, j}\right)_{k}$ are equal or smaller than the corresponding shortest significant range $\left(R_{p}\right)_{k}$ or differences $\left(\Delta_{i, j}\right)_{k}-\left(R_{p}\right)_{k}$ are negative, then we conclude that the pair of means in question is insignificantly different.

Thus, the conclusions of the Duncan test are as follows:

- $\quad$ of the $p=9$ treatment variants, 5 variants are insignificant, and 4 are significant

- insignificant treatment options are T2, T6, T7, T8, and T9

- $\quad$ significant treatment options are T1, T3, T4, and T5. 
Table 6. Values for the sizes and $\left(\Delta_{i, j}\right)_{k^{\prime}}\left(R_{p}\right)_{k}$ and $\left(\Delta_{i, j}\right)_{k}-\left(R_{p}\right)_{k}$ corresponding to case 3.2.

\begin{tabular}{cccc}
\hline Difference between Pairs of Variants, $\boldsymbol{k}$ & $\mathbf{2 6}$ & $\mathbf{3 3}$ & $\mathbf{3 5}$ \\
\hline Values for difference between pairs of variants, $\left(\Delta_{i, j}\right)_{k}$ & 39.0 & 78.0 & 78.0 \\
Values for shortest critical range, $\left(R_{p}\right)_{k}$ & 78.379 & -4.379 & 78.379 \\
Value of the difference, $\left(\Delta_{i, j}\right)_{k}-\left(R_{p}\right)_{k}$ & -39.379 & $\mathrm{~T} 8$ & -0.379 \\
Variant for superior rank & $\mathrm{T} 2$ & $\mathrm{~T} 9$ & $\mathrm{~T} 7$ \\
Variant for inferior rank & T6 \\
\hline
\end{tabular}

From Annex no.3 [40] for degrees of freedom $v=27$ the normal deviations were obtained by linear interpolation, with the probabilities of transgression

$P_{\%} \in\{5 \%, 1 \%, 0.1 \%\}$, as $\mathrm{t}_{5 \%}=2.05, \mathrm{t}_{1 \%}=2.77$ and $\mathrm{t}_{0.1 \%}=3.69$.

Then, we calculated, with the same probabilities $p \%$, the limit difference, DL, using the equation:

$$
D L=t \cdot \sigma_{d}
$$

where: $\sigma_{d}=260.1$ is the standard deviation related to average crop production, $\mathrm{S}_{\mathrm{r}}$.

Thus, the following values for DL resulted: $\mathrm{D}_{\mathrm{L} 5 \%}=533.20, \mathrm{DL}_{1 \%}=720.47$, and $\mathrm{DL}_{0.1 \%}=959.76$.

In Table 7, the differences between the crop productions corresponding to each variant (except for the control variant) and the production corresponding to the control variant (with the Rank $r=N_{v}=9$ ) are summarized:

$$
\Delta S_{r}=S_{r}-S_{N v}
$$

Table 7. Centralization of the data necessary for the classification of variants by the limit difference (DL) test.

\begin{tabular}{ccccccccc}
\hline Rank, $\boldsymbol{r}$ & $\mathbf{1}$ & $\mathbf{2}$ & $\mathbf{3}$ & $\mathbf{4}$ & $\mathbf{5}$ & $\mathbf{6}$ & $\mathbf{7}$ & $\mathbf{8}$ \\
\hline Difference of production, $\Delta S_{r}=S_{r}-S_{N v}$ & 881 & 675 & 563 & 385 & 346 & 266 & 192 & 114 \\
$\operatorname{sign}\left(\Delta S_{r}-D L 5 \%\right)$ & + & + & + & - & - & - & - & - \\
$\operatorname{sign}\left(\Delta S_{r}-D L 1 \%\right)$ & + & - & - & - & - & - & - & - \\
$\operatorname{sign}\left(\Delta S_{r}-D L 0.1 \%\right)$ & - & - & - & - & - & - & - \\
Significance & T5:DS & T4: S & T3: $S$ & T2:NS & T9:NS & T8:NS & T7:NS & T6:NS \\
\hline
\end{tabular}

For this purpose, the sign afferent to the respective differences was determined $\operatorname{sign}\left(\Delta S_{r}-D L 5 \%\right)$, a sign that establishes the meaning assigned to each variant:

(NS-insignificant; S-significant; DS—distinctly significant; FS—very significant).

The results thus obtained with the DL limit difference test are compatible and complementary with those of the Duncan test, but it cannot take into account the T1 variant.

In Figure 4 we can observe in the nine experimental variants that the highest number of pods per plant is for those on the soil treated with the Euphore-type sludge, where we had an average number of 137 pods per plant, compared to that of the soil treated with dry raw sludge with approximately 120.5 pods per plant, and that of the control soil with only 95 pods per plant.

In Table 8, the centralization of the data necessary for the classification of variants by DL test for the average number of beans/plants is presented. 


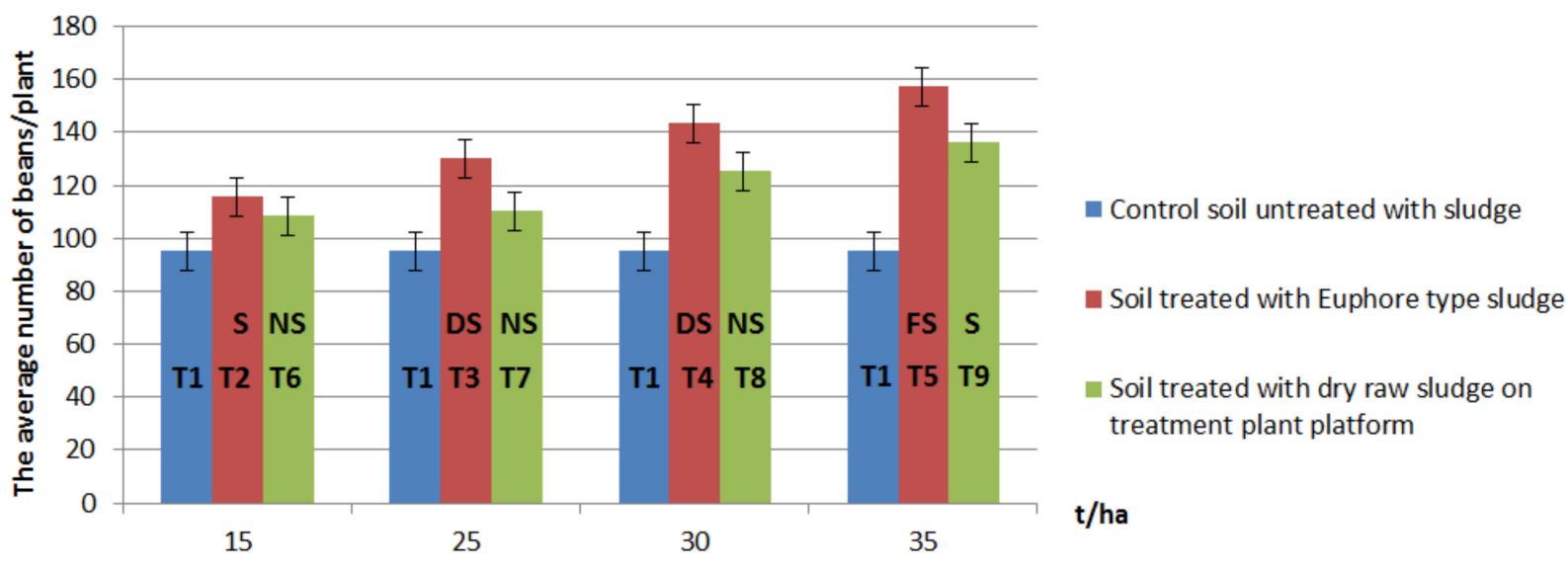

Figure 4. The average number of beans/plant for the soybean crops in the nine experimental variants. Error bar with standard error of deviation (\%).

Table 8. Centralization of the data necessary for the classification of variants by the DL test for the average number of beans/plants.

\begin{tabular}{ccccccccc}
\hline Rank, $\boldsymbol{r}$ & $\mathbf{1}$ & $\mathbf{2}$ & $\mathbf{3}$ & $\mathbf{4}$ & $\mathbf{5}$ & $\mathbf{6}$ & $\mathbf{7}$ & $\mathbf{8}$ \\
\hline Difference of number, $\Delta S_{r}=S_{r}-S_{N v}$ & 28.8 & 20.6 & 16.7 & 16 & 13.2 & 12 & 10.6 & 8 \\
$\operatorname{sign}\left(\Delta S_{r}-D L 5 \%\right)$ & + & + & + & + & + & - & - & - \\
$\operatorname{sign}\left(\Delta S_{r}-D L 1 \%\right)$ & + & + & + & - & - & - & - & - \\
$\operatorname{sign}\left(\Delta S_{r}-D L 0.1 \%\right)$ & + & - & - & - & - & - & - & - \\
Significance & T5: FS & T4:DS & T3:DS & T2: S & T9:S & T8:NS & T7:NS & T6:NS \\
\hline
\end{tabular}

Where: DL5\% $=13.0862$, DL1\%= 17.3276, DL0.1\%= 22.391, T1: Control variant.

Chemical analysis performed on the soybean plants (stems, roots) and grains highlighted the following aspects (Table 9):

- the roots of the soybean plant contained heavy metals below the maximum permissible values, except for $\mathrm{Pb}$ that exceeded the value by $0.45 \mathrm{mg} / \mathrm{kg}$ dry substance; the highest concentrations of $\mathrm{Pb}(15.45 \mathrm{mg} / \mathrm{kg}$ dry substance), $\mathrm{Cd}(0.19 \mathrm{mg} / \mathrm{kg}$ dry substance.), $\mathrm{Ni}(12.74 \mathrm{mg} / \mathrm{kg}$ dry substance.), $\mathrm{Cu}(8.8 \mathrm{mg} / \mathrm{kg}$ dry substance.), and $\mathrm{Zn}(29.4 \mathrm{mg} / \mathrm{kg}$ dry substance.) were obtained for the dose of $35 \mathrm{t} / \mathrm{ha}$, for the variant of soil treated with dry raw sludge.

- $\quad$ the stems of the soybean plant contained heavy metals below the maximum allowable values; the highest concentrations of $\mathrm{Pb}(13.98 \mathrm{mg} / \mathrm{kg}$ dry substance), $\mathrm{Cd}(0.17 \mathrm{mg} / \mathrm{kg}$ dry substance.), $\mathrm{Ni}(8.15 \mathrm{mg} / \mathrm{kg}$ dry substance), $\mathrm{Cu}(7.64 \mathrm{mg} / \mathrm{kg}$ dry substance), and $\mathrm{Zn}(23.45 \mathrm{mg} / \mathrm{kg}$ dry substance) were obtained for the dose of $35 \mathrm{t} / \mathrm{ha}$, for the variant of soil treated with dry raw sludge.

- $\quad$ soybeans had a heavy metal content below the maximum admissible values; the highest concentrations of $\mathrm{Pb}$ (11.34 mg/ $\mathrm{kg}$ dry substance), $\mathrm{Cd}(0.17 \mathrm{mg} / \mathrm{kg}$ dry substance), $\mathrm{Ni}(6.71 \mathrm{mg} / \mathrm{kg}$ dry substance), $\mathrm{Cu}(8.08 \mathrm{mg} / \mathrm{kg}$ dry substance), and Zn $(24.96 \mathrm{mg} / \mathrm{kg}$ dry substance) were obtained for the dose of $35 \mathrm{t} / \mathrm{ha}$, for the variant of soil treated with dry raw sludge.

- the concentration of $\mathrm{Ni}, \mathrm{Cu}$, and $\mathrm{Zn}$ in stems, roots, and beans were well below the level of toxicity in all organs of the soybean plant regardless of the applied dose. Rapeseed crops consume a lot of phosphorus. That is why it is recommended to fertilize the soil before sowing and plowing. The Pioneer PT225 Rapeseed Hybrid was chosen because it is resistant and it has good production. 
Table 9. The influence of different doses of sludge on the content of heavy metals in soybean stems, roots, and pods.

\begin{tabular}{|c|c|c|c|c|c|c|}
\hline \multirow[t]{2}{*}{$\begin{array}{l}\text { Dosage of Applied } \\
\text { Sludge }(t / h a)\end{array}$} & \multicolumn{2}{|c|}{ Control Soil Untreated with Sludge } & \multicolumn{2}{|c|}{ Soil Treated with Euphore-Type Sludge } & \multicolumn{2}{|c|}{$\begin{array}{c}\text { Soil Treated with Dry Raw Sludge from Treatmen } \\
\text { Plant Platform }\end{array}$} \\
\hline & Metal & $\begin{array}{l}\text { Quantity mg/kg Dry } \\
\text { Substance }\end{array}$ & Metal & $\begin{array}{l}\text { Quantity mg/kg Dry } \\
\text { Substance }\end{array}$ & Metal & $\begin{array}{l}\text { Quantity mg/kg Dry } \\
\text { Substance }\end{array}$ \\
\hline \multicolumn{7}{|c|}{ 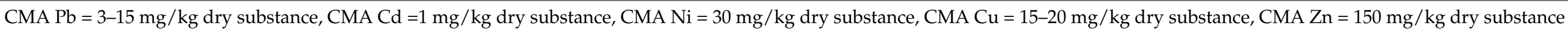 } \\
\hline \multicolumn{7}{|c|}{ 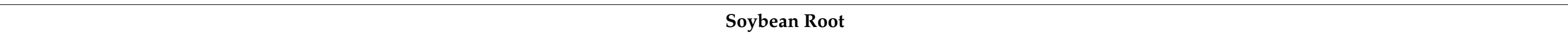 } \\
\hline \multirow{5}{*}{$15 \mathrm{t} / \mathrm{ha}$} & $\mathrm{Pb}$ & 11.89 & $\mathrm{~Pb}$ & 12.3 & $\mathrm{~Pb}$ & 12.8 \\
\hline & $\mathrm{Cd}$ & 0.11 & $\mathrm{Cd}$ & 0.12 & $\mathrm{Cd}$ & 0.13 \\
\hline & $\mathrm{Ni}$ & 8.5 & $\mathrm{Ni}$ & 9.2 & $\mathrm{Ni}$ & 9.6 \\
\hline & $\mathrm{Cu}$ & 6.25 & $\mathrm{Cu}$ & 6.84 & $\mathrm{Cu}$ & 7.13 \\
\hline & $\mathrm{Zn}$ & 22.3 & $\mathrm{Zn}$ & 22.75 & $\mathrm{Zn}$ & 23.6 \\
\hline \multirow{5}{*}{$25 \mathrm{t} / \mathrm{ha}$} & $\mathrm{Pb}$ & 12.45 & $\mathrm{~Pb}$ & 13.77 & $\mathrm{~Pb}$ & 14.02 \\
\hline & $\mathrm{Cd}$ & 0.12 & $\mathrm{Cd}$ & 0.13 & $\mathrm{Cd}$ & 0.14 \\
\hline & $\mathrm{Ni}$ & 9.7 & $\mathrm{Ni}$ & 10.4 & $\mathrm{Ni}$ & 10.78 \\
\hline & $\mathrm{Cu}$ & 7.11 & $\mathrm{Cu}$ & 7.65 & $\mathrm{Cu}$ & 7.98 \\
\hline & $\mathrm{Zn}$ & 23.15 & $\mathrm{Zn}$ & 25.75 & $\mathrm{Zn}$ & 26.06 \\
\hline \multirow{4}{*}{$30 \mathrm{t} / \mathrm{ha}$} & $\mathrm{Pb}$ & 13.6 & $\mathrm{~Pb}$ & 14.1 & $\mathrm{~Pb}$ & 14.59 \\
\hline & $\mathrm{Ni}$ & 10.78 & $\mathrm{Ni}$ & 11.89 & $\mathrm{Ni}$ & 12.16 \\
\hline & $\mathrm{Cu}$ & 7.86 & $\mathrm{Cu}$ & 8.27 & $\mathrm{Cu}$ & 8.98 \\
\hline & $\mathrm{Zn}$ & 25.7 & $\mathrm{Zn}$ & 26.29 & $\mathrm{Zn}$ & 27.02 \\
\hline \multirow{5}{*}{$35 \mathrm{t} / \mathrm{ha}$} & $\mathrm{Pb}$ & 14.4 & $\mathrm{~Pb}$ & 14.7 & $\mathrm{~Pb}$ & 15.45 \\
\hline & $\mathrm{Cd}$ & 0.17 & $\mathrm{Cd}$ & 0.18 & $\mathrm{Cd}$ & 0.19 \\
\hline & $\mathrm{Ni}$ & 12.4 & $\mathrm{Ni}$ & 12.66 & $\mathrm{Ni}$ & 12.74 \\
\hline & $\mathrm{Cu}$ & 8.4 & $\mathrm{Cu}$ & 8.67 & $\mathrm{Cu}$ & 8.8 \\
\hline & $\mathrm{Zn}$ & 26.8 & $\mathrm{Zn}$ & 28.7 & $\mathrm{Zn}$ & 29.4 \\
\hline \multicolumn{7}{|c|}{ Soybean Stem } \\
\hline \multirow{5}{*}{$15 \mathrm{t} / \mathrm{ha}$} & $\mathrm{Pb}$ & 10.65 & $\mathrm{~Pb}$ & 10.87 & $\mathrm{~Pb}$ & 11.23 \\
\hline & $\mathrm{Cd}$ & 0.9 & $\mathrm{Cd}$ & 0.10 & $\mathrm{Cd}$ & 0.11 \\
\hline & $\mathrm{Ni}$ & 4.3 & $\mathrm{Ni}$ & 4.76 & $\mathrm{Ni}$ & 5.12 \\
\hline & $\mathrm{Cu}$ & 5.35 & $\mathrm{Cu}$ & 5.64 & $\mathrm{Cu}$ & 6.15 \\
\hline & $\mathrm{Zn}$ & 20.1 & $\mathrm{Zn}$ & 20.64 & $\mathrm{Zn}$ & 21.2 \\
\hline
\end{tabular}


Table 9. Cont.

\begin{tabular}{|c|c|c|c|c|c|c|}
\hline \multirow{2}{*}{$\begin{array}{l}\text { Dosage of Applied } \\
\text { Sludge }(t / h a)\end{array}$} & \multicolumn{2}{|c|}{ Control Soil Untreated with Sludge } & \multicolumn{2}{|c|}{ Soil Treated with Euphore-Type Sludge } & \multicolumn{2}{|c|}{$\begin{array}{c}\text { Soil Treated with Dry Raw Sludge from Treatmen } \\
\text { Plant Platform }\end{array}$} \\
\hline & Metal & $\begin{array}{l}\text { Quantity mg/kg Dry } \\
\text { Substance }\end{array}$ & Metal & $\begin{array}{l}\text { Quantity mg/kg Dry } \\
\text { Substance }\end{array}$ & Metal & $\begin{array}{l}\text { Quantity mg/kg Dry } \\
\text { Substance }\end{array}$ \\
\hline \multirow{5}{*}{$25 \mathrm{t} / \mathrm{ha}$} & $\mathrm{Pb}$ & 11.8 & $\mathrm{~Pb}$ & 11.95 & $\mathrm{~Pb}$ & 12.12 \\
\hline & $\mathrm{Cd}$ & 0.10 & $\mathrm{Cd}$ & 0.11 & $\mathrm{Cd}$ & 0.12 \\
\hline & $\mathrm{Ni}$ & 5.6 & $\mathrm{Ni}$ & 6.16 & $\mathrm{Ni}$ & 6.54 \\
\hline & $\mathrm{Cu}$ & 5.85 & $\mathrm{Cu}$ & 6.41 & $\mathrm{Cu}$ & 6.85 \\
\hline & $\mathrm{Zn}$ & 21.2 & $\mathrm{Zn}$ & 22.34 & $\mathrm{Zn}$ & 23.12 \\
\hline \multirow{5}{*}{$30 \mathrm{t} / \mathrm{ha}$} & $\mathrm{Pb}$ & 12.9 & $\mathrm{~Pb}$ & 13.26 & $\mathrm{~Pb}$ & 13.68 \\
\hline & $\mathrm{Cd}$ & 0.12 & $\mathrm{Cd}$ & 0.13 & $\mathrm{Cd}$ & 0.14 \\
\hline & $\mathrm{Ni}$ & 6.73 & $\mathrm{Ni}$ & 7.25 & $\mathrm{Ni}$ & 7.56 \\
\hline & $\mathrm{Cu}$ & 6.37 & $\mathrm{Cu}$ & 6.89 & $\mathrm{Cu}$ & 7.12 \\
\hline & $\mathrm{Zn}$ & 21.85 & $\mathrm{Zn}$ & 22.58 & $\mathrm{Zn}$ & 22.97 \\
\hline \multirow[b]{3}{*}{$35 \mathrm{t} / \mathrm{ha}$} & $\mathrm{Pb}$ & 13.6 & $\mathrm{~Pb}$ & 13.79 & $\mathrm{~Pb}$ & 13.98 \\
\hline & $\mathrm{Cd}$ & 0.15 & $\mathrm{Cd}$ & 0.16 & $\mathrm{Cd}$ & 0.17 \\
\hline & $\mathrm{Ni}$ & 7.66 & $\mathrm{Ni}$ & 7.92 & $\mathrm{Ni}$ & 8.15 \\
\hline \multicolumn{7}{|c|}{ Soybean Beans } \\
\hline \multirow{5}{*}{$15 \mathrm{t} / \mathrm{ha}$} & $\mathrm{Pb}$ & 9.3 & $\mathrm{~Pb}$ & 9.7 & $\mathrm{~Pb}$ & 9.9 \\
\hline & $\mathrm{Cd}$ & 0.09 & $\mathrm{Cd}$ & 0.10 & $\mathrm{Cd}$ & 0.11 \\
\hline & $\mathrm{Ni}$ & 3.8 & $\mathrm{Ni}$ & 4.35 & $\mathrm{Ni}$ & 4.6 \\
\hline & $\mathrm{Cu}$ & 5.6 & $\mathrm{Cu}$ & 6.5 & $\mathrm{Cu}$ & 6.73 \\
\hline & $\mathrm{Zn}$ & 21.1 & $\mathrm{Zn}$ & 21.72 & $\mathrm{Zn}$ & 22.15 \\
\hline \multirow{5}{*}{$25 \mathrm{t} / \mathrm{ha}$} & $\mathrm{Pb}$ & 9.7 & $\mathrm{~Pb}$ & 10.11 & $\mathrm{~Pb}$ & 10.42 \\
\hline & $\mathrm{Cd}$ & 0.10 & $\mathrm{Cd}$ & 0.112 & $\mathrm{Cd}$ & 0.23 \\
\hline & $\mathrm{Ni}$ & 4.68 & $\mathrm{Ni}$ & 5.16 & $\mathrm{Ni}$ & 5.46 \\
\hline & $\mathrm{Cu}$ & 6.3 & $\mathrm{Cu}$ & 7.02 & $\mathrm{Cu}$ & 7.41 \\
\hline & $\mathrm{Zn}$ & 22.15 & $\mathrm{Zn}$ & 22.9 & $\mathrm{Zn}$ & 23.11 \\
\hline
\end{tabular}


Table 9. Cont.

\begin{tabular}{|c|c|c|c|c|c|c|}
\hline \multirow{2}{*}{$\begin{array}{l}\text { Dosage of Applied } \\
\text { Sludge ( } t / h a)\end{array}$} & \multicolumn{2}{|c|}{ Control Soil Untreated with Sludge } & \multicolumn{2}{|c|}{ Soil Treated with Euphore-Type Sludge } & \multicolumn{2}{|c|}{$\begin{array}{c}\text { Soil Treated with Dry Raw Sludge from Treatment } \\
\text { Plant Platform }\end{array}$} \\
\hline & Metal & $\begin{array}{l}\text { Quantity mg/kg Dry } \\
\text { Substance }\end{array}$ & Metal & $\begin{array}{l}\text { Quantity mg/kg Dry } \\
\text { Substance }\end{array}$ & Metal & $\begin{array}{l}\text { Quantity mg/kg Dry } \\
\text { Substance }\end{array}$ \\
\hline \multirow{5}{*}{$30 \mathrm{t} / \mathrm{ha}$} & $\mathrm{Pb}$ & 10.1 & $\mathrm{~Pb}$ & 10.71 & $\mathrm{~Pb}$ & 11.08 \\
\hline & $\mathrm{Cd}$ & 0.11 & $\mathrm{Cd}$ & 0.12 & $\mathrm{Cd}$ & 0.13 \\
\hline & $\mathrm{Ni}$ & 5.20 & $\mathrm{Ni}$ & 5.78 & $\mathrm{Ni}$ & 6.16 \\
\hline & $\mathrm{Cu}$ & 6.8 & $\mathrm{Cu}$ & 7.55 & $\mathrm{Cu}$ & 7.85 \\
\hline & $\mathrm{Zn}$ & 23.12 & $\mathrm{Zn}$ & 23.61 & $\mathrm{Zn}$ & 23.92 \\
\hline \multirow{5}{*}{$35 \mathrm{t} / \mathrm{ha}$} & $\mathrm{Pb}$ & 10.6 & $\mathrm{~Pb}$ & 11.12 & $\mathrm{~Pb}$ & 11.34 \\
\hline & $\mathrm{Cd}$ & 0.13 & $\mathrm{Cd}$ & 0.14 & $\mathrm{Cd}$ & 0.15 \\
\hline & $\mathrm{Ni}$ & 5.82 & $\mathrm{Ni}$ & 6.33 & $\mathrm{Ni}$ & 6.71 \\
\hline & $\mathrm{Cu}$ & 7.25 & $\mathrm{Cu}$ & 7.66 & $\mathrm{Cu}$ & 8.08 \\
\hline & $\mathrm{Zn}$ & 24.2 & $\mathrm{Zn}$ & 24.52 & $\mathrm{Zn}$ & 24.96 \\
\hline
\end{tabular}


The rapeseed was sown with about 55-60 seeds/sqm on September 1, 2019 at a distance between rows of about $15 \mathrm{~cm}$.

The fertilization was done in multiple phases according to the following scheme:

- Basic autumn fertilization at sowing and autumn foliar fertilization at the stage of 6-8 leaves.

- $\quad$ Phase fertilization I at the rosette stage, 8-11 leaves and phase fertilization II at the stage of the incipient floral buds.

- $\quad$ Spring foliar fertilization at the stage of green and yellow floral buds.

The experiments performed were multifactorial. For Factor a, the applied sludge doses were 5, 10, 20, and $30 \mathrm{t} / \mathrm{ha}$. For Factor $\mathrm{b}$, the sludge application systems were under plowing at the establishment of the crop and then once a year to the soil surface. For Factor $c$ the control variant was soil with sludge.

In the experimental plots with the two crops, sprinkler watering was applied by means of the drum and hose system with a Rain Sky-model $50 \mathrm{~F}$ with a 150 range.

The establishment of watering norms was made taking into account the critical phenophases of development of the studied plants: flowering, fruiting/formation, and filling of seeds.

For the rapeseed crop, two watering norms were applied, $\mathrm{m}_{1}=375 \mathrm{~m}^{3} / \mathrm{ha}(10 . \mathrm{IV})$ and $\mathrm{m}_{2}=400 \mathrm{~m}^{3} / \mathrm{ha}(29 . \mathrm{V})$, and for the soybean crop the watering norms were $\mathrm{m}_{1}=500 \mathrm{~m}^{3} / \mathrm{ha}$ (2.V) and $\mathrm{m}_{2}=550 \mathrm{~m}^{3} /$ ha (25.VII).

The lower watering norms applied to rapeseed are due to their more efficient use of water accumulated during the cold season and earlier harvesting, towards the end of June and early July, compared to soybeans that are harvested in September.

The average crop production and oil content of the rapeseed are shown in Table 10 for all nine experimental variants. As can be seen, the best percentage of rapeseed production is on the soil treated with Euphore-type sludge, with $5200 \mathrm{~kg} / \mathrm{ha}$, compared to that of the soil treated with dry sludge on the platform, which was about $4600 \mathrm{~kg} / \mathrm{ha}$, and that on the control soil, which was only $2356 \mathrm{~kg} / \mathrm{ha}$.

Table 10. Average crop production and oil content of the rapeseed.

\begin{tabular}{|c|c|c|c|c|c|c|}
\hline \multirow{2}{*}{$\begin{array}{l}\text { Dosage of Applied } \\
\text { Sludge (t/ha) }\end{array}$} & \multicolumn{2}{|c|}{$\begin{array}{l}\text { Control Soil Untreated } \\
\text { with Sludge }\end{array}$} & \multicolumn{2}{|c|}{$\begin{array}{l}\text { Soil Treated with } \\
\text { Euphore-Type Sludge }\end{array}$} & \multicolumn{2}{|c|}{$\begin{array}{l}\text { Soil Treated with Dry Raw Sludge } \\
\text { from Treatment Plant Platform }\end{array}$} \\
\hline & $\begin{array}{l}\text { Production } \\
\mathrm{kg} / \mathrm{ha}\end{array}$ & $\begin{array}{l}\text { Oil Content } \\
\text { of Rapeseed \% }\end{array}$ & $\begin{array}{l}\text { Production } \\
\text { kg/ha }\end{array}$ & $\begin{array}{l}\text { Oil Content } \\
\text { of Rapeseed \% }\end{array}$ & $\begin{array}{c}\text { Production } \\
\mathrm{kg} / \mathrm{ha}\end{array}$ & $\begin{array}{l}\text { Oil Content of } \\
\text { Rapeseed \% }\end{array}$ \\
\hline 5 & & & $\mathrm{~T} 2=4250$ & $\mathrm{~T} 2=46.1$ & $\mathrm{~T} 6=4046$ & $\mathrm{~T} 6=41.4$ \\
\hline 10 & & & $\mathrm{~T} 3=4920$ & $\mathrm{~T} 3=46.5$ & $\mathrm{~T} 7=4223$ & $\mathrm{~T} 7=42.2$ \\
\hline 20 & $\mathrm{~T} 1=2356$ & $\mathrm{~T} 1=37.5$ & $\mathrm{~T} 4=5050$ & $\mathrm{~T} 4=47.2$ & $\mathrm{~T} 8=4450$ & $\mathrm{~T} 8=43.1$ \\
\hline 30 & & & $\mathrm{~T} 2=5200$ & $\mathrm{~T} 5=48$ & $\mathrm{~T} 9=4600$ & $\mathrm{~T} 9=44$ \\
\hline
\end{tabular}

Rapeseed oil production, $O$, was computed with the following equation:

$$
O=S \cdot C / 100
$$

where $S$ is the seed crop production $(\mathrm{kg} / \mathrm{ha})$ and $C$ is oil content $(\%)$.

The values for $\mathrm{S}$ and $\mathrm{C}$ were taken from Table 10, and the values calculated for $\mathrm{O}$ are entered, in descending order, in Table 11.

Table 11. Values for average rapeseed oil production, in descending order.

\begin{tabular}{|c|c|c|c|c|c|c|c|c|c|c|}
\hline Rank, $r$ & 1 & 2 & 3 & 4 & 5 & 6 & 7 & 8 & 9 & Mean \\
\hline Variant & $\mathrm{T} 5$ & $\mathrm{~T} 4$ & $\mathrm{~T} 3$ & T9 & $\mathrm{T} 2$ & $\mathrm{~T} 8$ & $\mathrm{~T} 7$ & T6 & $\mathrm{T} 1$ & - \\
\hline Average oil production, $O_{r},(\mathrm{~kg} / \mathrm{ha})$ & 2496 & 2383.6 & 2287.8 & 2024 & 1959.25 & 1917.95 & 1782.11 & 1675.04 & 883.5 & 1934.36 \\
\hline Standard error, $\sigma_{r},(\%)$ & 9.94 & 22.04 & 25.74 & 26.82 & 28.08 & 18.84 & 20.05 & 21.58 & 22.77 & 21.76 \\
\hline
\end{tabular}


Because the same values were considered as those in the case of rapeseed crop production, for the following basic data, $\alpha=5 \%=0.05$ and $N_{V}=9 ; v=27$ the same values resulted for both standardized critical values for functions $\gamma_{p}=\gamma(p)$ and $R_{p}=R(p)$ from Table 4 and for all sizes entered in Table $12 \gamma_{p}=\gamma(p)$.

Table 12. The values for the sizes $\left(\Delta_{i, j}\right)_{k^{\prime}}\left(R_{P}\right)_{k}$ and $\left(\Delta_{i, j}\right)_{k}-\left(R_{p}\right)_{k}$ related to case 3.2.

\begin{tabular}{cc}
\hline Difference between Pairs of Variants, $k$ & 30 \\
\hline Values for difference between pairs of variants, $\left(\Delta_{i, j}\right)_{k^{\prime}}(\mathrm{Kg} / \mathrm{ha})$ & 41.30 \\
Values for shortest critical range, $\left(R_{P}\right)_{k^{\prime}}(\mathrm{Kg} / \mathrm{ha})$ & 63.18 \\
Values for difference $\left(\Delta_{i, j}\right)_{k}-\left(R_{p}\right)_{k^{\prime}}(\mathrm{Kg} / \mathrm{ha})$ & -21.88 \\
Variant for superior rank, $i(i=5)$ & $\mathrm{T} 9$ \\
Variant for inferior rank, $j(j=6)$ & $\mathrm{T} 8$ \\
\hline
\end{tabular}

The values for the sizes, $\left(\Delta_{i, j}\right)_{k}=\left(O_{i}\right)_{k}-\left(O_{j}\right)_{k^{\prime}}\left(R_{P}\right)_{k}$ and $\left(\Delta_{i, j}\right)_{k}-\left(R_{p}\right)_{k^{\prime}}$ related only to case 3.2., are summarized in Table 11.

Thus, the conclusions of the Duncan test for the average rapeseed oil production are as follows:

- $\quad$ of the $p=9$ treatment variants, 2 variants are insignificant, and 7 are significant;

- $\quad$ insignificant treatment options are T8 and T9;

- $\quad$ significant treatment options are T1, T2, T3, T4, T5, T6, and T7.

Similar to the application regarding soybean crop production, with degrees of freedom $v=27$, for the normal deviation $t$, the same values were obtained: $t_{5 \%}=2.05, t_{1} \%=2.77$, and $\mathrm{t}_{0.1 \%}=3.69$.

Then, for the corresponding standard deviation $\sigma_{d}=293.62, \mathrm{DL}_{5} \%=533.20$,

$\mathrm{DL}_{1 \%}=720.47$, and $\mathrm{DL}_{0.1 \%}=959.76$. Finally, with the data centralized in Table 13, the classification of variants $\mathrm{T} 2, \mathrm{~T} 3, \ldots, \mathrm{T} 9$ was performed. $\Delta O_{r}=O_{r}-O_{N v}$

Table 13. Centralization of the data necessary for the classification of variants by the DL test.

\begin{tabular}{ccccccccc}
\hline Rank, $\boldsymbol{r}$ & $\mathbf{1}$ & $\mathbf{2}$ & $\mathbf{3}$ & $\mathbf{4}$ & $\mathbf{5}$ & $\mathbf{6}$ & $\mathbf{7}$ & $\mathbf{8}$ \\
\hline Difference of production, $\Delta O_{r}=O_{r}-O_{N v}$ & 1612.5 & 1500 & 1404.3 & 1140.5 & 1075.75 & 1034.45 & 898.61 & 791.54 \\
$\operatorname{sign}\left(\Delta O_{r}-D L 5 \%\right)$ & + & + & + & + & + & + & + & + \\
$\operatorname{sign}\left(O S_{r}-D L 1 \%\right)$ & + & + & + & + & + & + & + & - \\
$\operatorname{sign}\left(S_{r}-D L 0.1 \%\right)$ & + & + & + & + & - & - & - & - \\
Significance & T5:FS & T4:FS & T3:FS & T9:FS & T2:DS & T8:DS & T7:DS & T6:S \\
\hline
\end{tabular}

The results for DL test in Table 13 are compatible and complementary to those in the Duncan test.

In Table 14 the average values of the agrochemical characteristics of the soil in the experimental field at the end of the vegetation period are presented. As can be seen, the best values are for the soil treated with Euphore-type sludge (V2), for which there is an increase in the amount of humus up to $3.4 \%$ in the Am horizon, compared to $2.03 \%$ (V3) in the variant fertilized with $25 \mathrm{t} / \mathrm{ha}$. The total nitrogen content of the soil was also influenced by the application of urban sludge, the values being between $0.088-0.160 \mathrm{mg} / 100 \mathrm{~g}$ for the variants with untreated soil and $0.23-0.21 \mathrm{mg} / 100 \mathrm{~g}$ for the variants where urban sludge was applied. The total phosphorus analyzed for the soil from the experimental variants had low values in the untreated variants, $1.8-2.2 \mathrm{mg} / 100 \mathrm{~g}$, and in the variants in which sludge was applied, a relatively proportional increase was found with the applied dose, with values of at 4.2 to $9.5 \mathrm{mg} / 100 \mathrm{~g}$. 
Table 14. Average values of agrochemical soil characteristics in the experiment.

\begin{tabular}{|c|c|c|c|c|}
\hline \multirow{3}{*}{$\begin{array}{l}\text { Chemical Indicators } \\
\text { that were Determined }\end{array}$} & \multirow{3}{*}{ Unit of Measurement } & \multicolumn{3}{|c|}{ Values of the Indices } \\
\hline & & \multicolumn{3}{|c|}{ Dose of Sludge Applied: 20 t/ha } \\
\hline & & $\begin{array}{l}\text { Control Soil, } \\
\text { Untreated with } \\
\text { Sludge, V1 }\end{array}$ & $\begin{array}{l}\text { Soil Treated with } \\
\text { Euphore-Type } \\
\text { Sludge, V2 }\end{array}$ & $\begin{array}{l}\text { Soil Treated with Dry Raw } \\
\text { Sludge from Treatment Plant } \\
\text { Platform, V3 }\end{array}$ \\
\hline $\mathrm{pH}$ & & 7.34 & 7.52 & 7.85 \\
\hline Total nitrogen & $\mathrm{mg} / 100 \mathrm{~g}$ & 0.16 & 0.23 & 0.21 \\
\hline $\mathrm{P}_{2} \mathrm{O}_{5}$ & $\mathrm{mg} / 100 \mathrm{~g}$ & 2.2 & 9.5 & 4.2 \\
\hline $\mathrm{K}_{2} \mathrm{O}$ & $\mathrm{mg} / 100 \mathrm{~g}$ & 14.9 & 24.5 & 18.6 \\
\hline $\mathrm{Pb}$ & $\mathrm{mg} / \mathrm{kg}$ & 8.9 & 10.1 & 13.7 \\
\hline $\mathrm{Cd}$ & $\mathrm{mg} / \mathrm{kg}$ & 0.60 & 0.61 & 0.65 \\
\hline $\mathrm{Cr}$ & $\mathrm{mg} / \mathrm{kg}$ & 65.9 & 68.6 & 70.4 \\
\hline $\mathrm{Ni}$ & $\mathrm{mg} / \mathrm{kg}$ & 4.1 & 4.3 & 4.8 \\
\hline $\mathrm{Cu}$ & $\mathrm{mg} / \mathrm{kg}$ & 16.1 & 16.6 & 17.3 \\
\hline $\mathrm{Zn}$ & $\mathrm{mg} / \mathrm{kg}$ & 12.3 & 14.42 & 15.2 \\
\hline
\end{tabular}

Field—for the applied dose of $20 \mathrm{t} / \mathrm{ha}$ of sludge.

Regarding the $\mathrm{pH}$, in the untreated variants, it had values between 7.32 and 7.34, and in the treated variants it varied between 7.52 and 7.85. The content of heavy metals in the soil at the end of the period was intended to study the effect of urban sludge on the soil, and it was within the normal limits cited in the literature.

We considered that the soil reaction from the experimental variants was influenced by the mechanical dilution resulting from the sludge-soil sewage mixture and a higher rate of mineralization of the organic material from the sludge used in the experimental variants. Old manure obtained from animal waste fermentation also has a slight alkaline reaction and causes a slight increase in the $\mathrm{pH}$ values of acid soils [41-43].

The slight alkaline reaction of the soil in the experimental variants may be due to some mineral and organic substances that form stable organo-mineral complexes in the soil and lead to the blockage of hydrogen ions from the salt and organic acid buffer systems [44,45].

In assessing the effect of applying treatments to correct the soil reaction, both $\mathrm{pH}$ and $\mathrm{H}+$ ions modifications must be taken into account. At equal $\mathrm{pH}$ ranges, but ranging from different limits, the concentration of $\mathrm{H}+$ ions has different values. The $\mathrm{pH}$ values change very easily in the range between 6 and 8 .

\section{Conclusions}

The sludge from urban wastewater treatment is a source of macro and micronutrients that can be used in agriculture. The Euphore-type sludge introduced into the soils contains 2.55 more $\mathrm{K}$, in the form of organic complexes accessible to plants, and $1.1 \%$ more phosphate and nitrogen, than those found in naturally dried sludge.

The positive response of crops to the application of sludge from wastewater varies with the type of crop and soil conditions. The average soybean production obtained for the soil treated with Euphore-type sludge is about $30.6 \%$ higher than that of the control soil and about $12 \%$ higher compared to that of the soil treated with dry raw sludge.

Following the application of sludge processed at a Euphore plant, the content of heavy metals recorded in the soil and plants does not exceed the maximum permissible limits.

We recommend the application of sludge processed with a Euphore plant on agricultural land as it contributes to the improvement of some soil properties and to the increase of soybean production. The $\mathrm{Pb}, \mathrm{Cd}, \mathrm{Cu}, \mathrm{Ni}$, and $\mathrm{Zn}$ content of roots, stems, and berries are lower than the maximum allowable limits. 
Author Contributions: Conceptualization, E.C. and F.F.; conducted the field experiments E.C. and F.F.; software, E.C.; contributed to statistical processing and interpretation of data validation, E.C.; investigation, E.C. and F.F.; resources, E.C. and F.F.; data curation, E.C.; writing-original draft preparation, E.C.; writing-review and editing, E.C. and F.F.; visualization, E.C.; supervision, E.C. and F.F. All authors have read and agreed to the published version of the manuscript.

Funding: This research received no external funding.

Institutional Review Board Statement: Not applicable.

Informed Consent Statement: Not applicable.

Data Availability Statement: Authors ensure that data shared are in accordance with participants consent.

Conflicts of Interest: The authors declare no conflict of interest.

\section{References}

1. Adesodum, J.K.A.; Mbagwu, J.S.C.; Oti, N. Structural stability and carbohydrate contents of an ultisol under different management systems. Soil Till. 2001, 60, 135-142. [CrossRef]

2. Bittencourt, S.; Serrat, B.M.; Aisse, M.M.; Gomes, D. Sewage sludge usage in agriculture: A case study of its destination in the curitiba metropolitan region, paraná, Brazil. Water Air Soil Pollut. 2014, 225, 2074. [CrossRef]

3. Iticescu, C.; Georgescu, L.P.; Murariu, G.; Circiumaru, A.; Timofti, M. The characteristics of sewage sludge used on agricultural lands. AIP Conf. Proc. 2018, 2022, 020001. [CrossRef]

4. Tsadilas, C.D.; Hu, Z.; Bi, Y.; Nikoli, T. Utilization of coal fly ash and municipal sewage sludge in agriculture and for reconstruction of soils in disturbed lands: Results of case studies from Greece and China. Int. J. Coal Sci. Technol. 2018, 5, 64-69. [CrossRef]

5. Kirchmann, H.; Börjesson, G.; Kätterer, T.; Cohen, Y. From agricultural use of sewage sludge to nutrient extraction: A soil science outlook. Ambio 2017, 46, 143-154. [CrossRef]

6. Kocik, A.; Truchan, M.; Rozen, A. Application of willows (Salix viminalis) and earthworms (Eisenia fetida) in sewage sludge treatment. Eur. J. Soil Biol. 2007, 43, 327-331. [CrossRef]

7. Gherghel, A.; Teodosiu, C.; De Gisi, S.A. Review on wastewater sludge valorisation and its challenges in the context of circular economy. J. Clean. Prod. 2019, 228, 244-263. [CrossRef]

8. Duan, B.; Zhang, W.; Zheng, H.; Wu, C.; Zhang, Q.; Bu, Y. Disposal situation of sewage sludge from municipal wastewater treatment plants and assessment of the ecological risk of heavy metals for its land use in Shanxi, China. Int. J. Environ. Res. Public Health 2017, 14, 823. [CrossRef] [PubMed]

9. Ågren, G.I.; Wetterstedt, J.A.M. What determines the temperature response of soil organic matter decomposition. Soil Biol. Biochem. 2007, 39, 1794-1798. [CrossRef]

10. Nascimento, A.L.; de Souza, A.J.; Oliveira, F.C.; Coscione, A.R.; Viana, D.G.; Regitano, J.B. Chemical attributes of sewage sludges: Relationships to sources and treatments, and implications for sludge usage in agriculture. J. Clean. Prod. 2020, 258. [CrossRef]

11. Przydatek, G.; Wota, A.K. Analysis of the comprehensive management of sewage sludge in Poland. J. Mater. Cycles Waste Manag. 2020, 22, 80-88. [CrossRef]

12. Bazzoffi, P. Soil erosion tolerance and water runoff control: Minimum environmental standards. Reg. Environ. Chang. 2009, 9, 169-179. [CrossRef]

13. Chatterjee, A.; Lal, R. On farm assessment of tillage impact on soil carbon and associated soil quality parameters. Soil Tillage Res. 2009, 104, 270-277. [CrossRef]

14. Izaurralde, R.C.; Williams, J.R.; Post, W.M.; Thomson, A.M.; McGill, W.B. Long-term modeling of soil C erosion and sequestration at the small watershed scale. Clim. Chang. 2007, 80, 73-90. [CrossRef]

15. Alvarenga, P.; Farto, M.; Mourinha, C.; Palma, P. Beneficial use of dewatered and composted sewage sludge as soil amendments: Behaviour of metals in soils and their uptake by plants. Waste Biomass Valoriz. 2016, 7, 1189-1201. [CrossRef]

16. E-Correia, A.A.S.; Matos, M.P.S.R.; Gomes, A.R.; Rasteiro, M.G. Immobilization of heavy metals in contaminated soilsperformance assessment in conditions similar to a real scenario. Appl. Sci. 2020, 10, 7950. [CrossRef]

17. Eid, E.M.; Alrumman, S.A.; El-Bebany, A.F.; Hesham, A.E.-L.; Taher, M.A.; Fawy, K.F. The effects of different sewage sludge amendment rates on the heavy metal bioaccumulation, growth and biomass of cucumbers (Cucumis sativus L.). Environ. Sci. Pollut. Res. 2017, 24, 16371-16382. [CrossRef]

18. Gawdzik, J. Mobility of heavy metals in municipal sewage sludge from different throughput sewage treatment plants. Pol. J. Environ. Stud. 2012, 21, 1603-1611.

19. Parkpian, P.; Leong, S.T.; Preecha, L.; Torotoro, J. Influence of salinity and acidity on bioavailability of sludge-borne heavy metals. A case study of Bangkok municipal sludge. Water Air Soil Pollut. 2002, 139, 43-60.

20. Singh, R.P.; Agrawal, M. Variations in heavy metal accumulation, growth and yield of rice plants grown at different sewage sludge amendment rates. Ecotoxicol. Environ. Saf. 2010, 73, 632-641. [CrossRef] [PubMed]

21. Turek, A.; Wieczorek, K.; Wolf, W.M. Digestion Procedure and Determination of Heavy Metals in Sewage Sludge-An Analytical Problem. Sustainability 2019, 11, 1753. [CrossRef] 
22. Hamdi, H.; Hechmi, S.; Khelil, M.N.; Zoghlami, I.R.; Benzarti, S.; Tlili, S.M.; Hassen, A.; Jedidi, N. Repetitive land application of urban sewage sludge: Effect of amendment rates and soil texture on fertility and degradation parameters. Catena 2019, 172, 11-20. [CrossRef]

23. Farasat, S.; Namli, A. Evaluating effects of sewage sludge on soil biochemical properties amounts (incubation experiment). Fresenenius Environ. Bull. 2016, 25, 1484-1493.

24. Rastetter, N.; Gerhardt, A. Retraction Note to: Toxic potential of different types of sewage sludge as fertiliser in agriculture: Ecotoxicological effects on aquatic and soil indicator species. J. Soils Sediments 2016, 15, 565-577. [CrossRef]

25. Charlton, A.; Sakrabani, R.; Tyrrel, S.; Casado, M.R.; McGrath, S.P.; Crooks, B.; Campbell, C.D. Long-term impact of sewage sludge application on soil microbial biomass: An evaluation using meta-analysis. Environ. Pollut. 2016, 219, 1021-1035. [CrossRef] [PubMed]

26. Inglezakis, V.J.; Zorpas, A.; Karagiannidis, A.; Samaras, P.; Voukkali, I. European Union legislation on sewage sludge management. Fresenius Environ. Bull. 2014, 23, 635-639.

27. Deeks, L.; Chaney, K.; Murray, C.; Sakrabi, R.; Gedara, S. A new sludge-derived organo-mineral fertilizer gives similar crop yields as conventional fertilizers. Agron. Sustain. Dev. 2013, 33, 539-549. [CrossRef]

28. Lamastra, L.; Suciu, N.A.; Trevisan, M. Sewage sludge for sustainable agriculture: Contaminants' contents and potential use as fertilizer. Chem. Biol. Technol. Agric. 2018, 5, 10. [CrossRef]

29. Liu, H.-T. Achilles Heel of Environmental Risk from Recycling of Sludge to Soil as Amendment: A Summary in Recent Ten Years (2007-2016). Waste Manag. 2016, 56, 575-583. [CrossRef]

30. Singh, R.P.; Agrawal, M. Potential benefits and risks of land application of sewage sludge. Waste Manag. 2008, 28, 347-358. [CrossRef] [PubMed]

31. Jain, M.K.; Das, D. Estimation of sediment yield and areas of soil erosion and deposition for watershed prioritization using gis and remote sensing. Water Resour. Manag. 2010, 24, 2091-2112. [CrossRef]

32. Lindstrom, M.J. Effects of residue harvesting on water runoff, soil erosion and nutrient loss. Agric. Ecosyst. Environ. 1986, 16, 103-112. [CrossRef]

33. Wiechmann, C.; Dienemann, C.; Kabbe, S.; Brandt, I.; Vogel, A.R. Klärschlammentsorgung in der Bundesrepublik Deutschland. Für Umweltbundesamt. 2012. Available online: http:/ / opus.kobv.de/zlb/volltexte/2012/13541/pdf/4280.pdf (accessed on 15 December 2020).

34. Florea, N.; Munteanu, I. Romanian System of Soil Taxonomy; Estfalia Press: Bucharest, Romania, 2012; ISBN 978-606-112-0901.

35. Stoica, E.; Rauta, C.; Florea, N. Methods of Soil Chemical Analysis; Research Institute of Soil Science and Agrochemestry: Bucharest, Romania, 1986.

36. Jităreanu, G. Experimental Technique; “Ion Ionescu de la Brad” Publishing House: Iaşi, Romania, 2000; p. 256. ISBN 973-98979-3-2.

37. ISO 659. Oilseeds-Determination of Oil Content-Reference Method. 2009. Available online: https://www.iso.org/standard/43169.html (accessed on 1 February 2021).

38. FOSFA. Technical Manual. Available online: https://www.fosfa.org/technical-2/technical-manual/ (accessed on 8 March 2021).

39. Harter, L.H.; Balakrishnan, N. Tables for the Use of Range and Studentized Range in Test of Hypotheses; CRC Press: Boca Raton, FL, USA, 1997; p. 677. ISBN 0-8493-3114-5.

40. Tehnica Experimentala. Available online: https://www.yumpu.com/ro/document/read/62662785/tehnica-experimentala (accessed on 10 March 2021).

41. Dumitru, E.; Calciu, I.; Carabulea, V.; Canarache, A. Metode de Analiza Utilizate in Laboratorul de Fizica a Solulu (Analysis Methods Use in Soil Physics Laboratory); Sitech Press: Craiova, Romania, 2009; ISBN 978-606-530-752-0.

42. Lixandru, G. Sisteme Integrate de Fertilizare in Agricultura (Integrated Fertilization Systems in Agriculture); "Ion Ionescu de la Brad" Publishing House: Iaşi, Romania, 2006; p. 357. ISBN 9737967067.

43. Lăcătușu, R.; Lungu, M.; Rizea, N. Global Chemestry; Terra Nostra Publishing House: Iași, Romania, 2017 ; p. 70. ISBN 978-606-623-0742.

44. Filpov, F. Pedologie (Pedology); "Ion Ionescu de la Brad" Publishing House: Iaşi, Romania, 2005; p. 444. ISBN 973-7921-64-X.15.

45. Lixandru, G.; Filipov, F. Organic Fertilizers. Environmental Quality Protection; "Ion Ionescu de la Brad", Publishing House: Iaşi, Romania, 2012; p. 420. ISBN 978-973-147-093-1. 